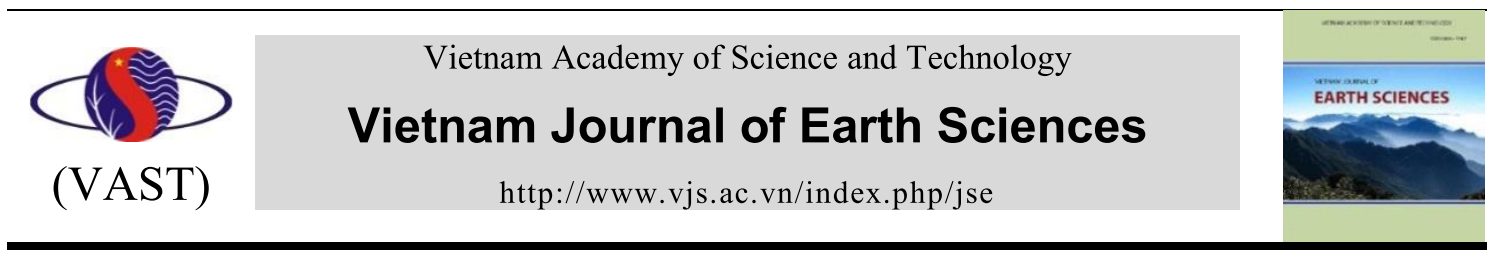

\title{
Adsorption of arsenic and heavy metals from solutions by modified iron ore sludge
}

\author{
Nguyen Quoc Bien, Nguyen Thi Hoang $\mathrm{Ha}^{*}$ \\ VNU University of Science, Vietnam National University, Hanoi, Vietnam
}

Received 23 January 2019; Received in revised form 12 June 2019; Accepted 10 July 2019

\begin{abstract}
Water pollution with arsenic (As) and heavy metals has been a major considering issue because of their negative impact on ecosystems and human health. This study was conducted to evaluate the adsorption behavior of As and heavy metals by iron ore sludge modified by the addition of $10 \%$ sodium silicate solution and heating at $400^{\circ} \mathrm{C}$ (SBC2-400-10S) in both batches and fixed-bed column experiments. The kinetics showed that the removal of As and heavy metals by the adsorbent is a pseudo-second-order reaction. The adsorption data fitted well with Langmuir isotherm and provided Langmuir monolayer capacity $(\mathrm{mg} / \mathrm{g})$ of As and heavy metals in the following order: $\mathrm{Pb}$ $(2.379)>\mathrm{Cd}(2.008)>\mathrm{Zn}(1.915)>\mathrm{Mn}$ (1.692) $>\mathrm{As}$ (0.452). The column adsorption data were fairly well described by Thomas model, with the order of Thomas adsorption capacity following a similar trend as in the batch study. The results of this study indicated that SBC2-400-10S was a potential adsorbent for removal of As and heavy metals from solutions.
\end{abstract}

Keywords: Adsorption; arsenic; heavy metal; iron ore sludge; modified; removal.

C2019 Vietnam Academy of Science and Technology

\section{Introduction}

The presence of arsenic (As) and heavy metals in water due to natural processes and anthropogenic activities is a major problem worldwide. Their toxic effects are well documented (Nagajyoti et al., 2010; Sillanpää and Oikari, 1996; Tchounwou et al., 2012). Numerous treatment techniques have been employed to eliminate or reduce heavy metals in wastewater including precipitation (Matlock et al., 2002), adsorption (Feng et al., 2013), ion exchange (Barakat et al., 2013), coagulation-sedimentation (Charerntanyarak,

"Corresponding author, Email: hoangha.nt@vnu.edu.vn
1999), and reverse osmosis (Bakalár et al., 2009). Adsorption by activated carbon is currently considered the best available technology for the reduction of heavy metals; however, its manufacturing cost is quite high (Shafeeyan et al., 2010).

Solid wastes from mining extraction have been reported to adsorb As and heavy metals from water (Feng and van Deventer, 2004; Iakovleva and Sillanpaa, 2013; Ozdes et al., 2009). The use of mining wastes for wastewater remediation appears to be a costeffective and environment-friendly approach that couples the benefits of treatment of both solid wastes and wastewater (Ahmaruzzaman, 
2011; Gupta et al., 2012). A wide range of industrial wastes and mining by-products are generally used in adsorption process such as clay-bearing mining wastes (Edeltrauda and Rafał, 2012), red mud (Çoruh and Ergun, 2011; Hülya et al., 2003; Pepper et al., 2018; Thuy et al., 2016), coal mine drainage sludge (Hung, 2014), iron ore slimes (Panda et al., 2011), and waste mud from copper mine (Ozdes et al., 2009). However, few studies have investigated the capacity of iron ore sludge to remove heavy metals from solutions. In fact, the fine grain-size of ore sludge may make it difficult to be applied in treatment systems. Therefore, the modification was essentially required to provide suitable grain-size particles and increase removal capacity. The adsorbent can be modified by acid treatment (Christidis et al., 1997; Valenzuela and Santos, 2001), alkali treatment ( $\mathrm{Hu}$ et al., 2012; Vlasova et al., 2007; Zaidi et al., 2018) or surface activation (Azha et al., 2019; Eren et al., 2009; Xiong and Peng, 2008).

The aim of this study is to investigate the adsorption capacity of the adsorbent (SBC2400-10S) modified from Ban Cuon iron ore sludge in both batches and fixed-bed column experiments.

\section{Materials and Methods}

\subsection{Preparation of adsorbent and solutions}

Iron ore sludge (SBC) was obtained from Ban Cuon iron processing area, Cho Don district, Bac Kan province, northern Vietnam. The total ore reserve is $2,353,881$ tons; mining capacity is 285,000 tons of raw ore/year; processing capacity is 200,000 tons of refined ore/year; the total amount of ore sludge is $3,000-3,500 \mathrm{~m}^{3} /$ year. Raw materials were dried using the NIIVE OVER KD200 oven at $80^{\circ} \mathrm{C}$ until the sample weight was constant. Samples were crushed using the MRC laboratory Equipment Manufac User and sieved to obtain particles from 0.16 to $0.25 \mathrm{~mm}$ which was reported to be optimal grain-size for adsorption capacity (Mellah and Chegrouchethe, 1996).

The sludge was modified by adding $10 \%$ sodium silicate to mix with raw material (SBC). The specific gravity of sodium silicate solution was $1.46 \pm 0,01 \mathrm{~g} / \mathrm{ml}$, and its contents of $\mathrm{Na}_{2} \mathrm{O}$ and $\mathrm{SiO}_{2}$ were $11.5 \% \sim 12.2$ and $27.5 \% \sim 29.5 \%$, respectively. The mixture was pressed using 2mm-diameter size machine to make granular form. For the calcination, the sample was placed in a porcelain dish and then heated at temperatures of $400^{\circ} \mathrm{C}$ for 3 hours by Calcinor LabTech. This adsorbent (SBC2-400-10S) was cooled in a desiccator, and preserved in closed vessels for further batch and fixed-bed column experiments.

Arsenic, manganese $(\mathrm{Mn})$, lead $(\mathrm{Pb})$, cadmium $(\mathrm{Cd})$, and zinc $(\mathrm{Zn})$ were selected as target adsorbates to determine the adsorption characteristics of the adsorbent. Standard solutions $\quad\left(\mathrm{Mn}\left(\mathrm{NO}_{3}\right)_{2}, \quad \mathrm{Cd}\left(\mathrm{NO}_{3}\right)_{2} \cdot 4 \mathrm{H}_{2} \mathrm{O}\right.$, $\mathrm{Pb}\left(\mathrm{NO}_{3}\right)_{2}, \mathrm{Zn}\left(\mathrm{NO}_{3}\right)_{2}$, and $\left.\mathrm{Na}_{2} \mathrm{HAsO}_{4} \cdot 7 \mathrm{H}_{2} \mathrm{O}\right)$ (provided by Merck corporation) were separately diluted by Milli-Q water to obtain the desired concentrations of As and heavy metals for the experiments.

\subsection{Experimental design}

\subsubsection{Point of zero charge ( $p H_{P Z C}$ )}

$\mathrm{pH}_{\mathrm{PZC}}$ was determined following the method reported by Cerovic et al. (2017) and Minh (2010). The adsorbent was added to $100 \mathrm{~mL}$ solutions with initial $\mathrm{pH}$ ranging from 3.0 to 11.0. $\mathrm{NaOH} 0.1 \mathrm{M}$ and $\mathrm{HNO}_{3} 0.1 \mathrm{M}$ were used for $\mathrm{pH}$ adjustment in all experiments. The 
suspensions were agitated in a flat shaker at a shaking speed of $120 \mathrm{rpm}$ at $25 \pm 2^{\circ} \mathrm{C}$ for $24 \mathrm{~h}$. At the end of the experiment, the $\mathrm{pH}$ (equilibrium $\mathrm{pH}$ ) was determined. $\mathrm{pH}_{\mathrm{PZC}}$ was calculated by the following equation (Eq.1):

$$
\Delta \mathrm{pH}=\mathrm{pH}_{(1)}-\mathrm{pH}_{(2)}
$$

where $\mathrm{pH}_{(1)}$ and $\mathrm{pH}_{(2)}$ are the $\mathrm{pH}$ values before and after the experiment, respectively.

The intersection of the connecting points line with the horizontal axis at the point $\Delta \mathrm{pH}=0$ indicates $\mathrm{pH}_{\mathrm{PZC}}$.

\subsubsection{Batch adsorption experiment}

The batch adsorption experiments were conducted using separate metal solutions. Approximately $2 \mathrm{~g}$ of adsorbent was subsequently added to $100 \mathrm{~mL}$ of aqueous adsorbate solution in a $125 \mathrm{~mL}$ plastic flask. The flask was covered with a parafilm and shaken at $120 \mathrm{rpm}$ on the orbital shaker (coded LSI-2 provided by Daihan Labtech Co., Ltd) at $25 \pm 2{ }^{\circ} \mathrm{C}$ until desirable time intervals. After predetermined time periods, the mixture of adsorbent and adsorbate (As, $\mathrm{Mn}, \mathrm{Cd}, \mathrm{Pb}$, or $\mathrm{Zn}$ ) was immediately separated using a $0.45 \mu \mathrm{m}$ syringe filter. Then, a $15 \mathrm{~mL}$ solution was collected for elemental analysis.

The amount of As and heavy metals adsorbed at equilibrium $\left(q_{e} ; \mathrm{mg} / \mathrm{g}\right)$ and at time $t$ $\left(q_{t} ; \mathrm{mg} / \mathrm{g}\right)$, was calculated by the following mass balance equations (Eqs.2-3):

$$
\begin{aligned}
& q_{e}=\frac{\left(C_{o}-C_{e}\right) V}{m} \\
& q_{t}=\frac{\left(C_{o}-C_{t}\right) V}{m}
\end{aligned}
$$

where $C_{o}(\mathrm{mg} / \mathrm{L}), C_{e}(\mathrm{mg} / \mathrm{L})$, and $C_{t}$ $(\mathrm{mg} / \mathrm{L})$ are the concentrations of adsorbate at the beginning, equilibrium, and time $t$, respectively; $\mathrm{m}(\mathrm{g})$ is the mass of used adsorbent, and V (L) presents the volume of the experimental solution.

Adsorption kinetic experiments were conducted on single solutions at a metal concentration of $20 \mathrm{mg} / \mathrm{L}$ using $100 \mathrm{~mL}$ glass flasks. The suspensions were agitated in a flat shaker at $120 \mathrm{rpm}$ at $25 \pm 2{ }^{\circ} \mathrm{C}$. The initial $\mathrm{pH}$ values of the solutions were adjusted to $5.5 \pm 0.2$. The kinetic study was conducted within a specific duration of 10-1440 min.

Adsorption isotherm was conducted in various initial concentrations of metals $(0-50$ $\mathrm{mg} / \mathrm{L}$ ). Approximately $2 \mathrm{~g}$ of adsorbent was added to $100 \mathrm{~mL}$ of a solution containing target metal. The flasks were immediately covered with a parafilm and shaken at $120 \mathrm{rpm}$ at the same conditions of kinetic experiments.

Each experiment was performed in duplicate, and blank samples without the adsorbent were also conducted simultaneously. If the bias of the repeated experiment exceeded $15 \%$, a triplicate run was performed (Sdiri and Higashi, 2013).

\subsubsection{Column adsorption experiment}

Fixed-bed column experiments were performed using the same design reported by Chinh et al. (2016) (Fig. 1). Approximately $50 \mathrm{~g}$ of SBC2-400-10S was put in a plastic cylinder of volume $\times$ diameter $\times$ height $=$ $60 \mathrm{~mL} \times 3 \mathrm{~cm} \times 11.5 \mathrm{~cm}$ (Fig. 1). Constant water flow rate $(2 \mathrm{~mL} /$ minute $)$ was set based on the optimal retention time of 30 minutes. The concentrations of $\mathrm{Mn}, \mathrm{Pb}, \mathrm{Zn}, \mathrm{As}$, and $\mathrm{Cd}$ in the present experiment were 4.0, 0.6, 1.5, 0.4 , and $0.1 \mathrm{mg} / \mathrm{L}$, respectively. These metal concentrations were similar to those in wastewater in the Cho Don $\mathrm{Pb}-\mathrm{Zn}$ mine, $\mathrm{Bac}$ Kan province. The column experiment was carried out in 25 days. 


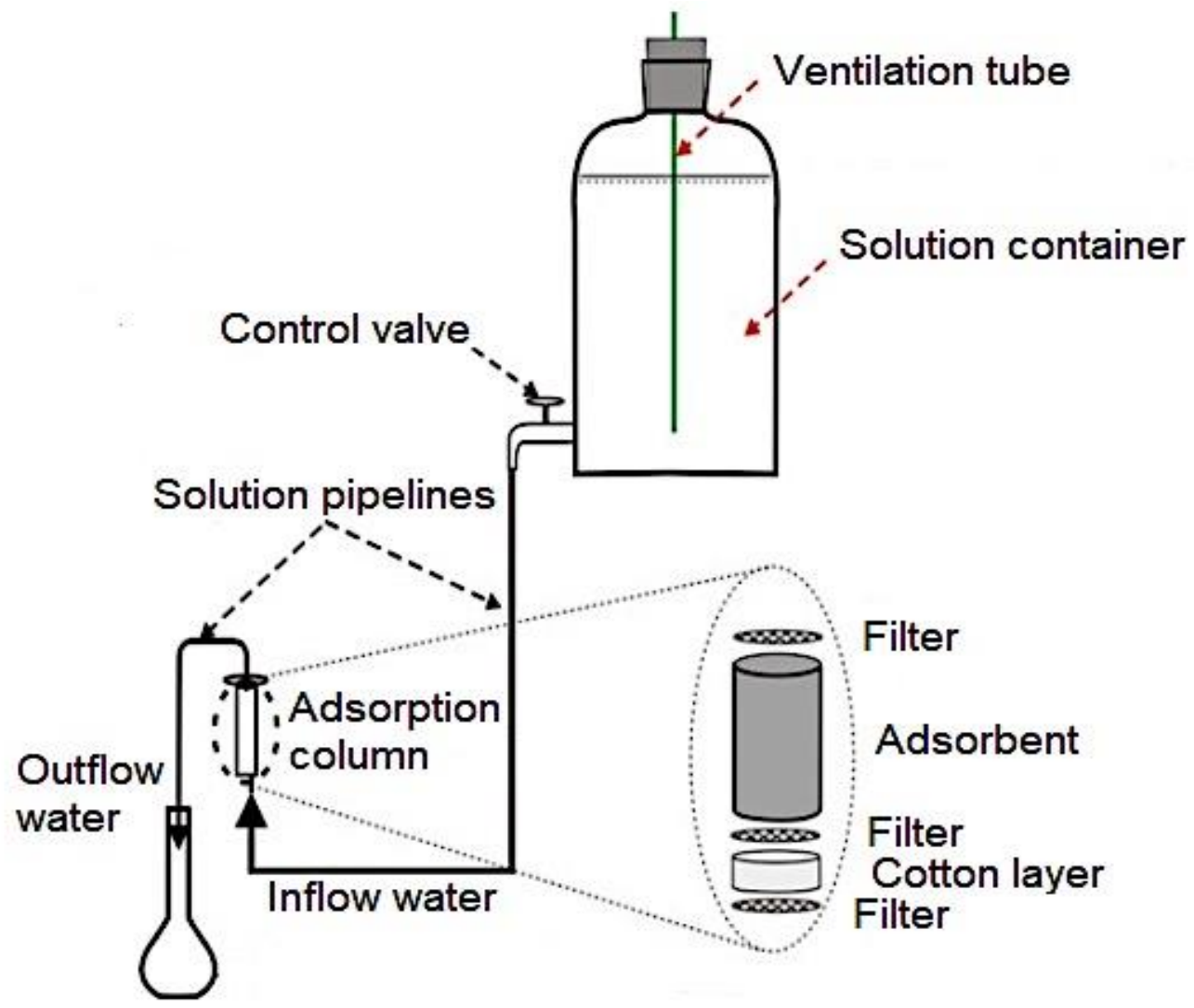

Figure 1. Schematic diagram of the designed fixed-bed column

\subsection{Analytical methods}

The mineralogical compositions of the adsorbent were determined on powder samples by X-ray diffraction analysis (XRD, D5005, Siemens). The XRD was equipped with a $\mathrm{Cu}(\mathrm{K} \alpha 1,2)$ target employed at $40 \mathrm{kV}$ and $30 \mathrm{~mA}$ with a setting of $3-70^{\circ}(2 \theta)$, step time $0.02^{\circ}(2 \theta)$. The Brunauer-Emmett-Teller method (BET, Gemini VII 2390 Surface Area Analyzer, Micromeritics) was operated to estimate the specific surface areas $\left(\mathrm{S}_{\mathrm{BET}}\right)$. Cation exchange capacity (CEC) was determined using a particle charge detector (PCD, Mütek 05). Fourier transform infrared spectroscopy (FTIR, Nicolet iS5, Thermo Scientific) was used to determine the vibration frequency changes in the functional groups in the adsorbent.
The suspensions in water samples were separated through a $0.45 \mu \mathrm{m}$ nylon syringe filter (Cole-Parmer). Elemental analysis was performed by Atomic Absorption Spectrometer (AAS, Agilent 240FS with hydride generation accessory VGA77).

All measurements were conducted at the Key Laboratory of Geoenvironment and Climate Change Response (GEO-CRE), VNU University of Science, Vietnam National University, Hanoi, Vietnam.

\section{Results and discussion}

\subsection{Characteristics of adsorbent (SBC2-400- 10S)}

The results of mineral compositions (XRD) showed that the percentage of quartz, kaolinite, goethite, hematite, and muscovite in 
the adsorbent was $43,12,4,7$, and $13 \%$, respectively. The mineral composition of the adsorbent differed from that of the original iron ore sludge (SBC). The most obvious change was a decrease of goethite composition from 20 to $4 \%$ and an increase of hematite from 3 to $7 \%$ after the modification (Table 1). This result is possibly due to the decomposition of iron hydroxides, aluminum hydroxides or the phase transition of the oxides at high temperature $\left(400^{\circ} \mathrm{C}\right)$. This is in accordance with the result reported by Minh et al. (2010) that goethite structure was destroyed at a temperature from $300^{\circ} \mathrm{C}$ to $420^{\circ} \mathrm{C}$ and transferred to $\alpha \mathrm{Fe}_{2} \mathrm{O}_{3}$ hematite. In addition, we found an increase in the proportion of some minerals with the capability of metal adsorption (e.g., kaolinite, muscovite, illite, and hematite), indicating better metal adsorption efficiency of the modified adsorbent (SBC2-400-10S) (Uddin, 2017)

Table 1. Mineral and chemical compositions

\begin{tabular}{|c|c|c|c|c|c|}
\multicolumn{2}{|c|}{$\begin{array}{c}\text { Mineral composition } \\
\text { (wt.\%) }\end{array}$} & \multicolumn{3}{c|}{$\begin{array}{c}\text { Chemical composition } \\
\text { (wt.\%) }\end{array}$} \\
\hline & $\mathrm{SBC}$ & $\begin{array}{c}\text { SBC2- } \\
400-10 \mathrm{~S}\end{array}$ & & $\mathrm{SBC}$ & $\begin{array}{c}\text { SBC2- } \\
400-10 \mathrm{~S}\end{array}$ \\
\hline Quartz & 39 & 43 & $\mathrm{SiO}_{2}$ & 43.6 & 46.6 \\
\hline Kaolinite & 11 & 12 & $\mathrm{Al}_{2} \mathrm{O}_{3}$ & 21.7 & 17.7 \\
\hline Muscovite & 10 & 13 & $\mathrm{Fe}_{2} \mathrm{O}_{3}$ & 20.4 & 23.4 \\
\hline Illite & 7 & 13 & $\mathrm{MnO}$ & 0.44 & 0.92 \\
\hline Talc & 4 & 7 & $\mathrm{MgO}$ & 1.85 & 1.99 \\
\hline Goethite & 20 & 4 & $\mathrm{Zn}$ & 368 & 376 \\
\hline Hematite & 3 & 7 & $\mathrm{As}$ & 82.5 & 96.1 \\
\hline Magnetite & 2 & 1 & $\mathrm{Cd}$ & 63.3 & 83.4 \\
\hline Gibbsite & 3 & - & $\mathrm{Pb}$ & 112 & 146 \\
\hline Pyrite & 1 & - & & & \\
\hline
\end{tabular}

The result of FTIR analysis demonstrated the presence of O-H (H-bonded), Si-O-Si and $\mathrm{Si}-\mathrm{OH}$ that were recognized by the peaks at roughly 3620, 1031, and $778 \mathrm{~cm}^{-1}$, respectively. The presence of the high amount of silica and hydroxyl groups may enhance the adsorptive capacity of the adsorbent (Sdiri et al., 2010). The results showed a similarity in $\mathrm{Si}-\mathrm{O}-\mathrm{Si}, \mathrm{Si}-\mathrm{OH}$, and hydroxyl groups with the original sludge (SBC) (Nguyen et al., 2019).

High BET and CEC values are often expected to the high binding capacity of potentially toxic metals in aqueous solutions (Tran and Chao, 2018). BET and CEC values of $\mathrm{SBC} 2-400-10 \mathrm{~S}$ were $39.4 \mathrm{~m}^{2} / \mathrm{g}$ and 91 $\mathrm{mmol}_{\mathrm{c}(-)} \mathrm{Kg}^{-1}$, respectively. The lower value of BET and higher value of CEC were obtained when compared with the original sludge (SBC) (Table 2). These values were higher than those of some reported materials such as laterite (Maji et al., 2008; Thao et al., 2016), clay (Kayode et al., 2006; Jiang et al., 2009), and red mud (Hülya et al., 2003) (Table 2).

The electrical state of the adsorbent's surface in solution is characterized by the point of zero charge (PZC). The $\mathrm{pH}_{\mathrm{PZC}}$ of the adsorbent (SBC2-400-10S) was 9.8, higher than that of raw material $\left(\mathrm{pH}_{\mathrm{PZC}}=5.0\right)$ (Fig. 2 ). An increase in $\mathrm{pH}$ values with the addition of sodium silicate was due to the hydrolysis process which was produced by the reaction of the weak acid and strong base $\left(\mathrm{Na}_{2} \mathrm{SiO}_{3}\right)$.

Table 2. Comparison specific surface area (BET) and cation exchange capacity (CEC) of SBC2-400-10S with other materials

\begin{tabular}{|c|c|c|c|}
\hline & BET $\left(\mathrm{m}^{2} / \mathrm{g}\right)$ & $\begin{array}{c}\text { CEC } \\
\left(\mathrm{mmol}_{\mathrm{c}(-)} \cdot \mathrm{Kg}^{-1}\right)\end{array}$ & Authors \\
\hline SBC & 47.4 & 75 & \multirow{2}{*}{ This study } \\
\hline SBC2-400-10S & 39.4 & 91 & Maji et al., 2008 \\
\hline Laterite & 15.365 & - & Thao et al., 2016 \\
\hline Laterite (Hanoi, Vietnam) & - & 66 & Kayode et al., 2006; Jiang et al., 2009 \\
\hline Clay & $10-20$ & $15-75$ & Hülya et al., 2003 \\
\hline Red mud & 30 & 37 &
\end{tabular}




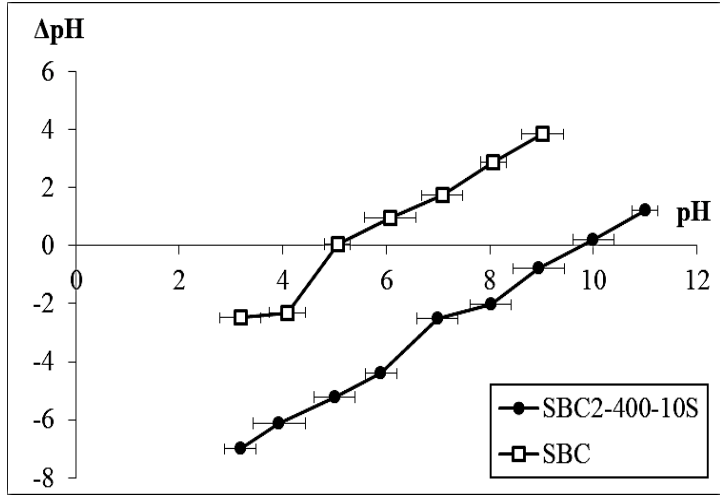

Figure 2. Zero charge point $\mathrm{pH}_{\mathrm{PZC}}$ of the adsorbent (SBC2-400-10S)

\subsection{Adsorption kinetics}

Adsorption kinetic experiments were conducted to define the rate of metals adsorption on the material. The results showed that the longer contact time to the metal solutions, the better adsorption capacity of adsorbent was obtained. However, after 6 hours of the experiment, the system reached the equilibrium, adsorption capacity tended to increase slowly (Fig. 3). The highest adsorption capacity $(\mathrm{mg} / \mathrm{kg})$ order for the metals during the experiment was $\mathrm{Pb}(815)>$ $\mathrm{Cd}(611)>\mathrm{Zn}$ (577) $>\mathrm{Mn}$ (427) $>$ As (209).

In this study, two kinetic models were applied to mathematically describe the intrinsic adsorption constants. The nonlinearized forms of the pseudo-first-order model (Lagergren, 1898) and pseudo-secondorder models (Blanchard et al., 1984) are expressed in the following equations:

$$
q_{t}=q_{e}\left(1-e^{-k_{1} t}\right)
$$

$$
q_{t}=\frac{q_{e}^{2} k_{2} t}{1+k_{2} q_{e} t}
$$

where $\mathrm{k}_{1}\left(\mathrm{~min}^{-1}\right)$ and $\mathrm{k}_{2}\left(\mathrm{~g} \cdot \mathrm{mg}^{-1} \cdot \mathrm{min}^{-1}\right)$ are the rate constants of the pseudo-first- and second-order models, respectively; $\mathrm{q}_{\mathrm{e}}(\mathrm{mg} / \mathrm{g}$ ) and $\mathrm{q}_{\mathrm{t}}(\mathrm{mg} / \mathrm{g})$ are the amounts of adsorbate uptake per mass of adsorbent at equilibrium and time $\mathrm{t}(\mathrm{min})$, respectively.

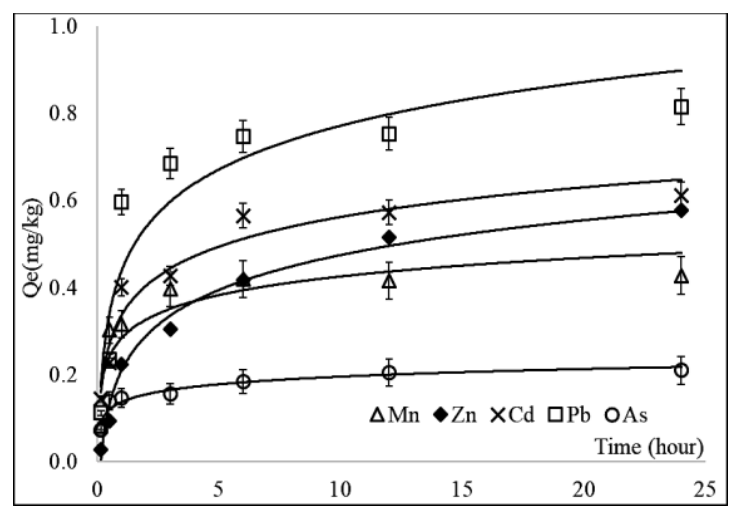

Figure 3. Effect of contact time on the adsorption of As and heavy metals

The kinetic adsorption data fitted satisfactorily to both pseudo-first and pseudosecond order models (Table 3). The models predicted equilibrium adsorption capacities were approximately equal to the corresponding experimental values for both models. When the $\mathrm{R}^{2}$ values were considered; however, the pseudo-second order model (0.908-0.941) appeared to fit the data better than the pseudo-first order model (0.8090.934). The better fit of the pseudo-second order model suggests that the adsorption process might be chemisorptions (Nur et al., 2014; Yang et al., 2011).

Table 3. Relative kinetic parameters (calculated by the non-linear method) for the adsorption processes of As and heavy metals

\begin{tabular}{|c|c|c|c|c|c|c|}
\hline \multirow{2}{*}{ Heavy metals } & \multicolumn{3}{|c|}{ Pseudo-first order } & \multicolumn{3}{c|}{ Pseudo-second order } \\
\cline { 2 - 7 } & $\mathrm{K}_{1}\left(\mathrm{~min}^{-1}\right)$ & $\mathrm{q}_{\mathrm{e}}(\mathrm{mg} / \mathrm{g})$ & $\mathrm{R}^{2}$ & $\mathrm{~K}_{2}\left(\mathrm{~g} \cdot \mathrm{mg}^{-1} \cdot \mathrm{min}^{-1}\right)$ & $\mathrm{q}_{\mathrm{e}}(\mathrm{mg} / \mathrm{g})$ & $\mathrm{R}^{2}$ \\
\hline $\mathrm{Mn}$ & 0.031 & 0.414 & 0.934 & 0.098 & 0.443 & 0.937 \\
\hline $\mathrm{Zn}$ & 0.003 & 0.580 & 0.926 & 0.005 & 0.716 & 0.941 \\
\hline $\mathrm{Cd}$ & 0.027 & 0.544 & 0.922 & 0.056 & 0.594 & 0.934 \\
\hline $\mathrm{Pb}$ & 0.014 & 0.769 & 0.931 & 0.026 & 0.839 & 0.941 \\
\hline $\mathrm{As}$ & 0.042 & 0.184 & 0.809 & 0.295 & 0.197 & 0.908 \\
\hline
\end{tabular}




\subsection{Adsorption isotherms}

In this study, the adsorption isotherms showed that the adsorption capacity decreased in the following order $\mathrm{Pb}>\mathrm{Cd}>\mathrm{Zn}>\mathrm{Mn}>$ As (Fig. 4). The Langmuir and Freundlich models are the simplest and most commonly used isotherms to represent the adsorption of compounds from a liquid phase onto a solid phase. The Langmuir model assumes monolayer adsorption onto homogeneous surface with a finite number of identical sites, while the Freundlich model is empirical in nature (Mohapatra et al., 2008). The Langmuir (Eq. 6) and Freundlich (Eq. 7) models were employed to describe the adsorptive behavior of selected adsorbates into the adsorbent. To minimize the respective error functions, the non-linear optimization technique was applied for calculating the adsorption parameters from these models:

$$
\begin{gathered}
q_{e}=\frac{Q_{\max }^{0} K_{L} C_{e}}{1+K_{L} C_{e}} \\
q_{e}=K_{F} C_{e}^{1 / n}
\end{gathered}
$$

where $\mathrm{q}_{\mathrm{e}}$ and $\mathrm{C}_{\mathrm{e}}$ are calculated by Eq. 2; $\mathrm{Q}_{\max }^{\mathrm{o}}(\mathrm{mg} / \mathrm{g})$ is the maximum saturated monolayer adsorption capacity of adsorbent; $\mathrm{K}_{\mathrm{L}}(\mathrm{L} / \mathrm{mg})$ is the Langmuir constant related to the affinity between an adsorbent and adsorbate; $K_{F}\left[(m g / g) /(m g / L)^{n}\right]$ presents the
Freundlich constant, which describes the intensity of adsorption; $1 / \mathrm{n}$ (dimensionless; $0<\mathrm{n}<10$ ) indicates a Freundlich intensity parameter, implying the magnitude of the adsorption driving strength or surface heterogeneity.

The parameters of adsorption models are shown in Table 4. The coefficients $\left(\mathrm{R}^{2}\right)$ of the Langmuir model (0.811-0.951) were higher than those of the Freundlich model $(0.784$ 0.923), indicating that the adsorption characteristics of the metals were adequately described by the Langmuir model. This result suggested that the adsorption sites were homogeneous with monolayer adsorption coverage (Yang et al., 2011).

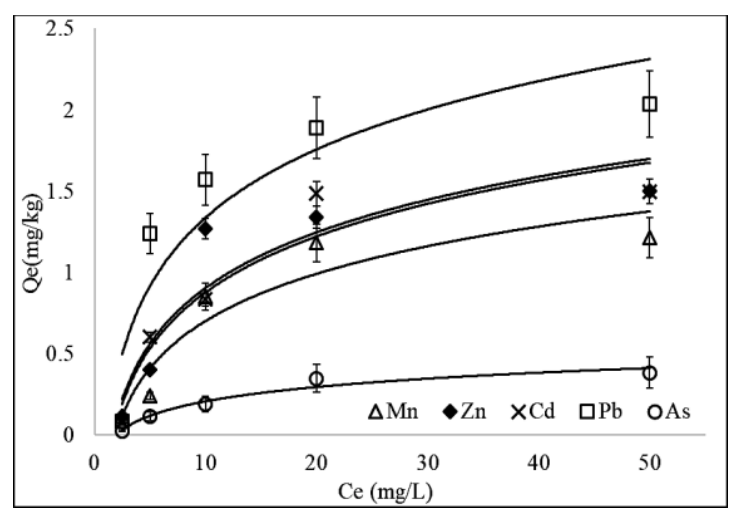

Figure 4. Adsorption isotherm of As and heavy metals onto the adsorbent (SBC2-400-10S)

Table 4. Adsorption isotherm parameters for As and heavy metals

\begin{tabular}{|c|c|c|c|c|c|c|}
\hline \multirow{2}{*}{ Heavy metals } & \multicolumn{3}{|c|}{ Langmuir parameters } & \multicolumn{3}{c|}{ Freundlich parameters } \\
\cline { 2 - 7 } & $Q_{\max }^{o}(\mathrm{mg} / \mathrm{g})$ & $\mathrm{K}_{\mathrm{L}}(\mathrm{L} / \mathrm{mg})$ & $\mathrm{R}^{2}$ & $\mathrm{~K}_{\mathrm{F}}(\mathrm{mg} / \mathrm{g}) /(\mathrm{mg} / \mathrm{L}) \mathrm{n}$ & $\mathrm{n}$ & $\mathrm{R}^{2}$ \\
\hline $\mathrm{Mn}$ & 1.692 & 0.126 & 0.930 & 0.275 & 0.486 & 0.844 \\
\hline $\mathrm{Zn}$ & 1.915 & 0.174 & 0.907 & 0.397 & 0.434 & 0.802 \\
\hline $\mathrm{Cd}$ & 2.008 & 0.140 & 0.951 & 0.359 & 0.465 & 0.878 \\
\hline $\mathrm{Pb}$ & 2.379 & 0.284 & 0.917 & 0.687 & 0.359 & 0.784 \\
\hline $\mathrm{As}$ & 0.452 & 0.137 & 0.811 & 0.073 & 0.524 & 0.923 \\
\hline
\end{tabular}

The Langmuir maximum adsorption capacity $(\mathrm{mg} / \mathrm{g})$ of target ions were in the following order: $\mathrm{Pb}(2.379)>\mathrm{Cd}(2.008)>\mathrm{Zn}$ $(1.915)>\operatorname{Mn}(1.692)>$ As $(0.452)$. The order of adsorption capacities may be due to the ion radius of heavy metals $\left(\mathrm{Pb}^{2+}, \mathrm{Cd}^{2+}, \mathrm{Mn}^{2+}\right.$, and $\mathrm{Zn}^{2+}$ ) that affected the charge density of ions.
The greater the cation radius, the smaller the charge density and vice versa, in which $\mathrm{r}_{\mathrm{Pb}}\left(1.2 \mathrm{~A}^{\circ}\right)>\mathrm{r}_{\mathrm{Cd}}\left(0.97 \mathrm{~A}^{\circ}\right)>\mathrm{r}_{\mathrm{Zn}}\left(0.74 \mathrm{~A}^{\circ}\right)>\mathrm{r}_{\mathrm{Mn}}$ $\left(0.67 \mathrm{~A}^{\circ}\right)$ (Wasastjerna, 1923).

\subsection{Fixed-bed column experiment}

The concentrations of metals in the 
solutions decreased after discharging from the fixed-bed column. When the adsorbate solution passed through the column, the adsorption zone (where the bulk of adsorption takes place) started moving out of the column and the effluent concentration start rising with time. This is termed as the breaking point. The time taken for the effluent concentration to reach a specific breakthrough concentration of interest is called the breakthrough time. In this study, breakthrough time $\left(\mathrm{t}_{\mathrm{b}} ; \mathrm{min}\right)$, breakthrough volume $\left(\mathrm{V}_{\mathrm{b}} ; \mathrm{L}\right)$, and the adsorption capacity of the adsorbent $\left(\mathrm{q}_{\mathrm{b}} ; \mathrm{mg} / \mathrm{g}\right)$ at $\mathrm{t}_{\mathrm{b}}$, can be obtained when the effluent concentration of target ions reaches $10 \%$ of the influent value $\left(\mathrm{C}_{\mathrm{t}} / \mathrm{C}_{0}=0.1\right)$. Adsorption of heavy metals by SBC2-400$10 \mathrm{~S}$ is presented in the form of breakthrough curves (Fig. 5). The breakthrough time (corresponding to $10 \%$ effluent concentration) for $\mathrm{Mn}, \mathrm{Zn}, \mathrm{Cd}, \mathrm{Pb}$ and As were found to be 127.4, 47.2, 70.6, 72.3, and $52.5 \mathrm{~h}$, respectively. The corresponding volumes of the metal bearing water treated were 15.3, 5.7, 8.5, 8.7, and $6.3 \mathrm{~L}$, respectively.

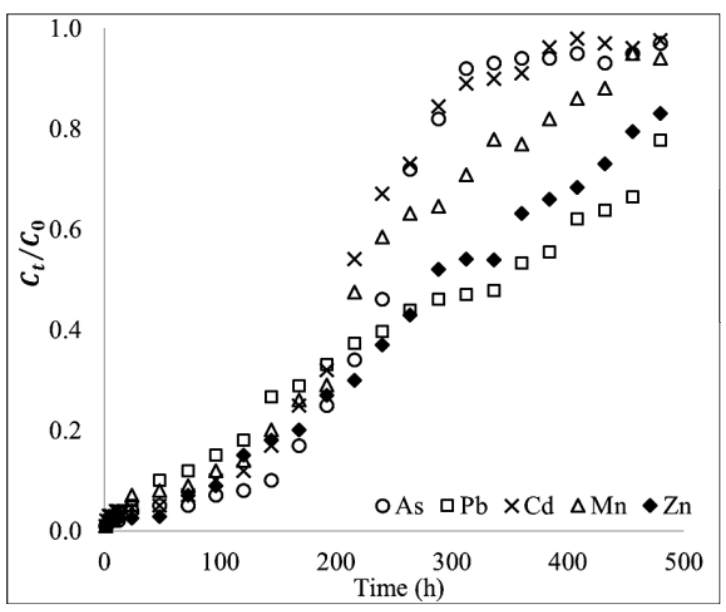

Figure 5. Breakthrough curves of column experiment

To analyze the breakthrough profiles in the fixed-bed adsorption process, Thomas mathematical model was applied to describe the dynamic adsorption behavior of SBC2-
400-10S in the fixed-bed column. The nonlinear and linear forms of the Thomas model are described in Eq.8 and Eq.9, respectively:

$$
\begin{aligned}
& \frac{C_{t}}{C_{0}}=\frac{1}{1+\exp \left(k_{T h} q_{0} \frac{m_{3}}{Q}-k_{T h} C_{0} t\right)} \\
& \ln \left(\frac{C_{0}}{C_{t}}-1\right)=K_{T h} q_{0} \frac{m_{3}}{Q}-k_{T h} C_{0} t
\end{aligned}
$$

where $\mathrm{k}_{\mathrm{Th}}(\mathrm{mL} / \mathrm{min} \mathrm{mg})$ is the Thomas adsorption rate constant; $\mathrm{q}_{0}(\mathrm{mg} / \mathrm{g})$ indicates the column maximum equilibrium heavy metals uptake per gram of adsorbent; $\mathrm{m}_{3}$ presents the mass of adsorbent used in the column; $\mathrm{Q}(\mathrm{mL} / \mathrm{min})$ is the volumetric flow rate.

The results of the column studies are summarized in Table 5. The order of column adsorption capacities calculated from the breakthrough curves $(\mathrm{Pb}>\mathrm{Zn}>\mathrm{Mn})$ agreed fairly well with that obtained from the batch adsorption experiments (Table 4).

Table 5. Breakthrough adsorption capacities and Thomas model parameters for column adsorption of As and heavy metals

\begin{tabular}{|c|c|c|c|c|c|c|}
\hline $\begin{array}{l}\text { Heavy } \\
\text { metals }\end{array}$ & $\mathrm{Q}(\mathrm{mL} / \mathrm{min})$ & $\begin{array}{c}C_{0} \\
(\mathrm{mg} / \mathrm{L})\end{array}$ & $\begin{array}{c}\text { Bed } \\
\text { height } \\
(\mathrm{mm})\end{array}$ & $\begin{array}{c}q_{0} \\
(\mathrm{mg} / \mathrm{g})\end{array}$ & $\begin{array}{c}k_{T h}(\mathrm{~mL} / \mathrm{min} \\
\mathrm{mg})\left(\times 10^{-3}\right)\end{array}$ & $R^{2}$ \\
\hline $\mathrm{Mn}$ & 2 & 20 & 100 & 0.148 & 0.21 & 0.97 \\
\hline $\mathrm{Zn}$ & 2 & 20 & 100 & 0.207 & 0.18 & 0.86 \\
\hline $\mathrm{Cd}$ & 2 & 0.5 & 100 & 0.085 & 0.52 & 0.94 \\
\hline $\mathrm{Pb}$ & 2 & 20 & 100 & 0.238 & 0.13 & 0.94 \\
\hline $\mathrm{As}$ & 2 & 1.0 & 100 & 0.029 & 0.13 & 0.85 \\
\hline
\end{tabular}

Generally, the maximum adsorption capacity of SBC2-400-10S from the Thomas model $\left(\mathrm{q}_{0}\right)$ was much lower than that from the Langmuir model $\left(Q_{\max }^{o}\right)$ for all of target heavy metals. This result is possibly due to the fact that the metals flowing through the columns did not reach equilibrium. In addition, the adsorption capacity in the column test was determined at lower heavy metal concentrations than the metal concentrations at which Langmuir adsorption maxima were determined. It is also noted that the adsorption process in the fixed-bed 
column is a dynamic process in an unstable state. The competition among metals in the same experimental solution might also be involved in lower adsorption capacity of the adsorbent in the column experiment than that in the batch experiment. These results are consistent with previous studies using experiments with similar operating conditions (Huang et al., 2009; Li and Champagne, 2009; Nguyen et al., 2015).

Table 6 shows a comparison of maximum adsorption capacity $\left(Q_{\max }^{o}\right)$ between modified iron ore sludge with some other adsorbents. The adsorption capacity of SBC2-400-10S was higher than that of the original iron ore sludge (SBC), with the exception of As. The decrease in adsorption capacity of As by SBC2-400-10S is possibly due to the decrease in the proportion of goethite after modification (Table 1). The efficiency of SBC2-40-10S is lower than some modified adsorbents (Minh, 2010; Giménez et al., 2010; Jiang et al., 2009; Ramana et al., 2010; Nguyen et al., 2015) (Table 6). This may indicate that heating modification combined with adhesives is not the best method to improve the adsorption efficiency of the adsorbent.

Table 6. Comparison of maximum adsorption capacity $\left(Q_{\max }^{o}\right)$ of some adsorbents

\begin{tabular}{|c|l|c|l|}
\hline Metals & \multicolumn{1}{|c|}{ Adsorbent } & $Q_{\max }^{o}(\mathrm{mg} / \mathrm{g})$ & \multicolumn{1}{c|}{ Authors } \\
\hline \multirow{3}{*}{ Mn } & SBC2-400-10S & 1.692 & This study \\
\cline { 2 - 4 } & SBC & 0.710 & Nguyen et al., 2019 \\
\cline { 2 - 4 } & PAC-Merck (Active carbon) & 15.438 & Minh, 2010 \\
\hline \multirow{5}{*}{$Z n$} & SBC2-400-10S & 1.915 & This study \\
\cline { 2 - 4 } & SBC & 0.745 & Nguyen et al., 2019 \\
\cline { 2 - 4 } & Activated carbon & 19.9 & Ramana et al., 2010 \\
\cline { 2 - 4 } & ICZ (Iron-coated zeolite) & 6.22 & Nguyen et al., 2015 \\
\hline \multirow{3}{*}{$\mathrm{Cd}$} & SBC2-400-10S & 2.008 & This study \\
\cline { 2 - 4 } & SBC & 0.771 & Nguyen et al., 2019 \\
\cline { 2 - 4 } & Activated carbon & 17.8 & Ramana et al., 2010 \\
\hline \multirow{5}{*}{$\mathrm{Pb}$} & SBC2-400-10S & 2.379 & This study \\
\cline { 2 - 4 } & SBC & 1.305 & Nguyen et al., 2019 \\
\cline { 2 - 4 } & Laterite (OBY) & 0.658 & Minh, 2010 \\
\cline { 2 - 4 } & PAC-Merck (Active carbon) & 63.850 & Minh, 2010 \\
\cline { 2 - 4 } & Modified kaolin & 32.2 & Jiang et al., 2009 \\
\hline \multirow{3}{*}{ As } & SBC2-400-10S & 0.452 & This study \\
\cline { 2 - 4 } & SBC & 1.113 & Nguyen et al., 2019 \\
\cline { 2 - 4 } & Laterite (OBY) & 0.702 & Minh, 2010 \\
\cline { 2 - 4 } & Modified red mud & 1.08 & Giménez et al., 2010 \\
\cline { 2 - 4 } & PAC-Merck (Active carbon) & 1.053 & Minh, 2010 \\
\hline
\end{tabular}

The concentrations of $\mathrm{Mn}, \mathrm{Zn}, \mathrm{Cd}, \mathrm{Pb}$, and As in outlet water during 25 days of the fixedbed column experiment were shown in Fig. 6 . The allowable limits set by Vietnamese regulation for industrial wastewater (QCVN 40:2011/BTNMT) at type A were 0.5, 3, 0.05, 0.1 , and $0.05 \mathrm{mg} / \mathrm{L}$, respectively; those at type B were $1,3,0.1,0.5$, and $0.1 \mathrm{mg} / \mathrm{L}$. The results of this experiment indicated that the concentrations of As and heavy metals in the effluent almost met the regulation due to adsorption efficiency of the adsorbent and medium concentrations of these metals in the influent. When the operation time of the column increased; however, the concentrations of metals in the effluent increased and exceeded the regulation levels (QCVN 40:2011/BTNMT)) (Fig. 6). 
Nguyen Quoc Bien, Nguyen Thi Hoang Ha/Vietnam Journal of Earth Sciences 41 (2019)

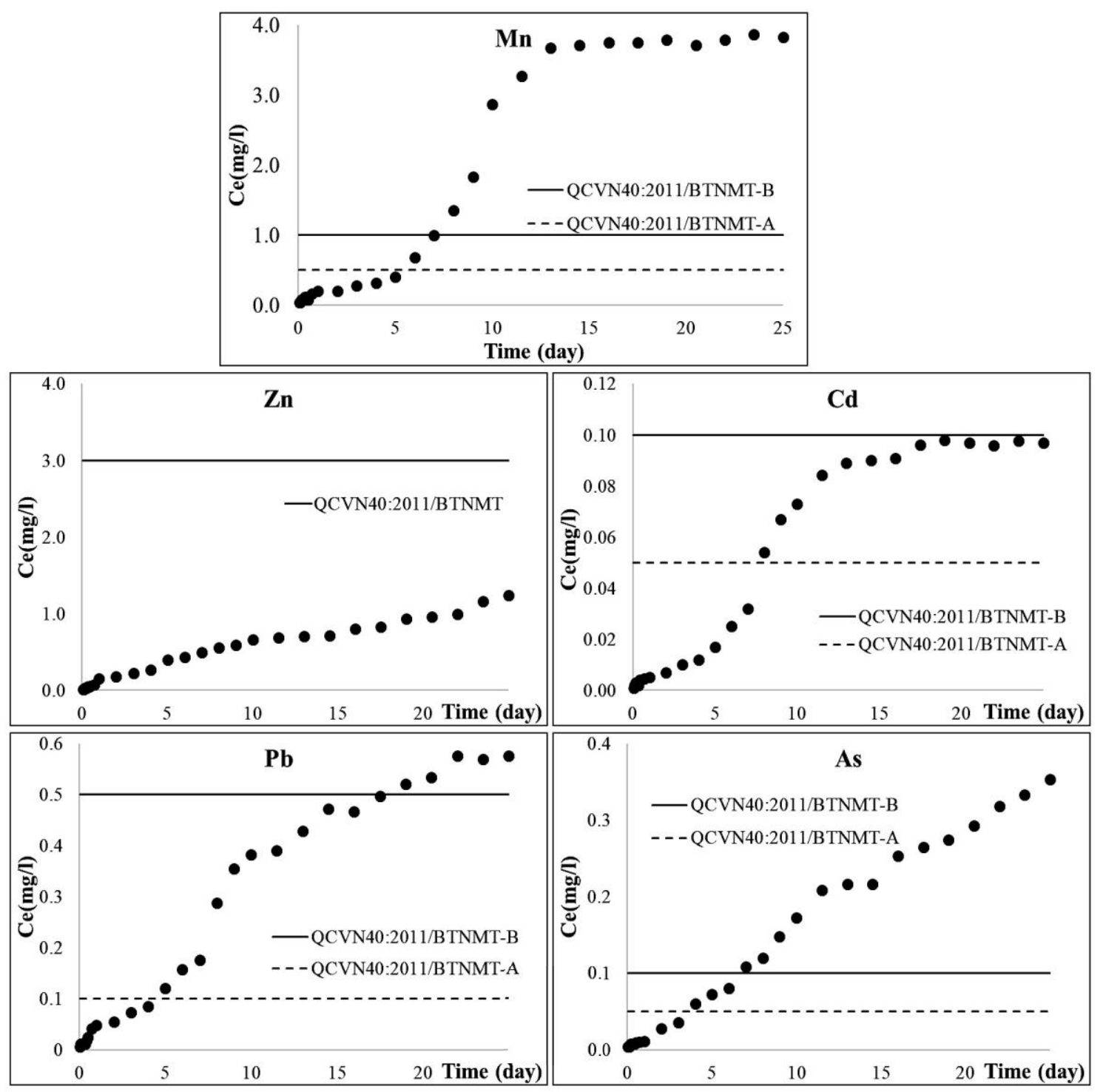

Figure 6. Concentrations of As and heavy metals in outflow water in the fixed-bed column experiment

\section{Conclusions}

In this study, modified iron ore sludge was found to be effective in removing As and heavy metals from the aqueous solutions. The kinetics showed that the removal of As and heavy metals by the adsorbent (SBC2-400$10 \mathrm{~S})$ is a pseudo-second-order reaction, proposing chemical adsorption. The adsorption data fitted well with Langmuir isotherm and yielded Langmuir monolayer capacity of metals in the order of $\mathrm{Pb}>\mathrm{Cd}>$ $\mathrm{Zn}>\mathrm{Mn}>\mathrm{As}$. The concentrations of As, Mn, and $\mathrm{Pb}$ in the effluent of fixed-bed column experiment were lower than those regulated by QCVN40:2011/BTNMT during 7, 7 and 16 days of the experiment, respectively. However, the simple fixed-bed column should be developed for individual ions. Desorption and reuse aspects also need to be considered 
before the application of this adsorbent for water treatment.

\section{Acknowledgments}

This research was supported by the National Science and Technology Program for Sustainable Development of Vietnam' Northwest Region (KHCN-TB.02C/13-18).

\section{References}

Ahmaruzzaman M., 2011. Industrial wastes as low-cost potential adsorbents for the treatment of wastewater laden with heavy metals. Advances in Colloid and Interface Science, 166, 36-59.

Azha S.F., Sellaoui L., Yunus E.H.E., Yee C.J., BonillaPetriciolet A., Lamine A.B., Ismail S., 2019. Ironmodified composite adsorbent coating for azo dye removal and its regeneration by photo-Fenton process: Synthesis, characterization and adsorption mechanism interpretation. Chemical Engineering Journal, 361, 31-40.

Bakalár T., Búgel M., Gajdošová L., 2009. Heavy metal removal using reverse osmosis. Acta Montanistica Slovaca, 14(3), 250.

Barakat M.A., Ismat Shah S., 2013. Utilization of anion exchange resin Spectra/Gel for separation of arsenic from water. Arabian Journal of Chemistry, 6(3), 307-311.

Blanchard G., Maunaye M., Martin G., 1984. Removal of heavy metals from waters by means of natural zeolites. Water Research, 18(12), 1501-1507.

Cerovic L.S., Milonjic S.K., Todorovic M.B., Trtanj M.I., Pogozhev Y.S., Blagoveschenskii Y., Levashov E.A., 2007. Point of zero charge of carbides. Colloids and Surfaces. Physicochemical and Engineering Aspects, 297, 1-6.

Charerntanyarak L., 1999. Heavy metals removal by chemical coagulation and precipitation. Water Science and Technology, 39(10-11), 135.

Chinh L.S., Nhuan M.T., Hai N.X., Hai N.T., Thang D.N., Giang N.T., Quy T.D., Ha N.T.H., 2016. The potential of modified iron mine drainage sludge for treatment of water contaminated with heavy metals. VNU Journal of Science-Earth and Environmental Sciences, 32(1S), 45-52.
Christidis G.E., Scott P.W., Dunham A.D., 1997. Acid Activation, Bleaching capacity of bentonites from the Islands of Milos and Chios, Aegean, Greece. Applied Clay Science, 12, 329-347.

Çoruh S., Ergun O.N., 2011. Copper Adsorption from Aqueous Solutions by Using Red Mud-An Aluminium Industry Waste. Springer, 1275-1282.

Edeltrauda H.R., Rafał W., 2012. Competitive sorption/desorption of $\mathrm{Zn}, \mathrm{Cd}, \mathrm{Pb}, \mathrm{Ni}, \mathrm{Cu}$, and $\mathrm{Cr}$ by clay-bearing mining wastes. Applied Clay Science, 65-66, 6-13.

Eren E., Afsin B., Onal Y., 2009. Removal of lead ions by acid activated and manganese oxide-coated bentonite. Journal of Hazardous Materials, 161(2-3), 677-685.

Feng D., van Deventer J.S.J., Aldrich C., 2004. Removal of pollutants from acid mine wastewater using metallurgical by-product slags. Separation and Purification Technology, 40, 61-67.

Feng Q., Zhanga F.Z., Chena Y., Chena L., Zhang Z., Chen C., 2013. Adsorption and desorption characteristics of arsenic on soils: kinetics, equilibrium, and effect of $\mathrm{Fe}(\mathrm{OH})_{2}$ colloid, $\mathrm{H}_{2} \mathrm{SiO}_{3}$ colloid and phosphate. Procedia Environmental Sciences, 18, 26-36.

Giménez J., De Pablo J., Martínez M., Rovira M., Valderrama C., 2010. Reactive transport of arsenic (III) and arsenic (V) on natural hematite: experimental and modeling. Journal of Colloid and Interface Science, 348(1), 293-297.

Gupta V.K., Rastogi A., Nayak A., 2012. Adsorption studies on the removal of hexavalent chromium from aqueous solution using a low cost fertilizer industry waste material. Journal of Colloid and Interface Science, 342, 135-141.

Hu J.L., He X.W., Wang C.R., Li J.W., Zhang C.H., 2012. Cadmium adsorption characteristic of alkali modified sewage sludge. Bioresource Technology, $121,25-30$.

Huang X., Liao X., Shi B., 2009. Adsorption removal of phosphate in industrial wastewater by using metalloaded skin split waste. Journal of Hazardous Materials, 166(2-3), 1261-1265.

Hülya G., Jens C.T., David M., Olaf S., 2003. Adsorption of arsenate from water using neutralized 
Nguyen Quoc Bien, Nguyen Thi Hoang Ha/Vietnam Journal of Earth Sciences 41 (2019)

red mud. Journal of Colloid and Interface Science, 264, 327-334.

Hung D.D., 2014. Assess the possibility of using some coal mine sludge in treating wastewater contaminated with heavy metals. VAST05.04/12-13.

Iakovleva E., Sillanpaa M., 2013. The use of low-cost adsorbents for wastewater purification in mining industries. Environmental Science and Pollution Research, 20(11), 7878-7899.

Jiang M., Wang Q., Jin X., Chen Z., 2009. Removal of $\mathrm{Pb}$ (II) from aqueous solution using modified and unmodified kaolinite clay. Journal of Hazardous Materials, 170, 332-339.

Jiang M.Q., Wang Q.P., Jin X.Y., Chen Z.L., 2009. Removal of $\mathrm{Pb}$ (II) from aqueous solution using modified and unmodified kaolinite clay. Journal of Hazardous Materials, 170(1), 332-339.

Kayode O.A., Iyayi E.U., Bamidele I.O., 2006. The effect of some operating variables on the adsorption of lead and cadmium ions on kaolinite clay. Journal of Hazardous Materials, B134, 130-139.

Lagergren S., 1898. About the theory of so-called adsorption of soluble substances. Kungliga Svenska Vetenskapsakademiens Handlingar, 24(4), 1-39.

Li C., Champagne, P., 2009. Fixed-bed column study for the removal of cadmium (II) and nickel (II) ions from aqueous solutions using peat and mollusk shells. Journal of Hazardous Materials, 171(1-3), 872-878.

Maji S.K., Pal A., Pal T., 2008. Arsenic removal from real-life groundwater by adsorption on laterite soil. Journal of Hazardous Materials, 151, 811-820.

Matlock M.M., Howerton B.S., Atwood D.A., 2002. Chemical precipitation of heavy metals from acid mine drainage. Water research, 36(19), 4757-4764.

Mellah A., Chegrouchethe S., 1996. The removal of zinc from aqueous solutions by natural bentonite. Water Research, 31(3), 621-629.

Minh N.T., 2010. Research on adsorbent based on natural mineral materials: basalt, laterite, clay to remove heavy metal and arsenic from contaminated wastewater. KC-02.25/06-10.

Mohapatra D., Mishra D., Park K.H., 2008. A laboratory scale study on arsenic (V) removal from aqueous medium using calcined bauxite ore. Journal of Environmental Sciences, 20(6), 683-689.

Nagajyoti P.C., Lee K.D., Sreekanth T.V.M., 2010. Heavy metals, occurrence and toxicity for plants: a review. Environmental Chemistry Letters, 8(3), 199-216.

Nguyen K.M., Nguyen B.Q., Nguyen H.T., Nguyen H.T.H., 2019. Adsorption of arsenic and heavy metals from solutions by unmodified iron-ore sludge. Applied Sciences, 9(4), 619.

Nguyen T.C., Loganathan P., Nguyen T.V., Vigneswaran S., Kandasamy J., Naidu R., 2015. Simultaneous adsorption of $\mathrm{Cd}, \mathrm{Cr}, \mathrm{Cu}, \mathrm{Pb}$, and $\mathrm{Zn}$ by an iron-coated Australian zeolite in batch and fixed-bed column studies. Chemical Engineering Science, 270, 393-404.

Nguyen T.C., Loganathan P., Nguyen T.V., Vigneswaran S., Kandasamy J., Naidu R., 2015. Simultaneous adsorption of $\mathrm{Cd}, \mathrm{Cr}, \mathrm{Cu}, \mathrm{Pb}$, and $\mathrm{Zn}$ by an iron-coated Australian zeolite in batch and fixed-bed column studies. Chemical Engineering Journal, 270, 393-404.

Nur T., Loganathan P., Nguyen T.C., Vigneswaran S., Singh G., Kandasamy J., 2014. Batch and column adsorption and desorption of fluoride using hydrous ferric oxide: solution chemistry and modelling. Chemical Engineering Science, 247, 93-102.

Ozdes D., Gundogdu A., Kemer B., Duran C., Senturk H.B., Soylak M., 2009. Removal of Pb(II) ions from aqueous solution by a waste mud from copper mine industry: equilibrium, kinetic and thermodynamic study. Journal of Hazardous Materials. 166, 1480-1487.

Panda L., Das B., Rao D.S., 2011. Studies on removal of lead ions from aqueous solutions using iron ore slimes as adsorbent. Korean Chemical Engineering Journal, 28(10), 2024-2032.

Pepper R.A., Couperthwaite S.J., Millar G.J., 2018. A novel akaganeite sorbent synthesised from waste red mud: Application for treatment of arsenate in aqueous solutions. Journal of Environmental Chemical Engineering, 6(5), 6308-6316.

QCVN40:2011-BTNMT. National Technical Regulation on Industrial Wastewater Quality. 
Vietnam Journal of Earth Sciences, 41(3), 259-271

Ramana D.K.V., Jamuna K., Satyanarayana B., Venkateswarlu B., Rao M. M., Seshaiah K., 2010. Removal of heavy metals from aqueous solutions using activated carbon prepared from Cicer arietinum. Toxicological and Environ Chemistry, 92(8), 1447-1460.

Sdiri A., Higashi T., 2013. Simultaneous removal of heavy metals from aqueous solution by natural limestones. Applied Water Science, 3(1), 29-39.

Sdiri A., Higashi T., Hatta T., Jamoussi F., Tase N., 2010. Mineralogical and spectroscopic characterization, and potential environmental use of limestone from the Abiod formation, Tunisia. Environmental Earth Sciences, 61, 1275-1287.

Shafeeyan M.S., Daud W.M.A.W., Houshmand A., Shamiri A., 2010. A review on surface modification of activated carbon for carbon dioxide adsorption. Journal of Analytical and Applied Pyrolysis, 89(2), 143-151.

Sillanpää M., Oikari A., 1996. Assessing the impact of complexation by EDTA and DTPA on heavy metal toxicity using microtox bioassay. Chemosphere, 32(8), 1485-1497.

Tchounwou P.B., Yedjou C.G., Patlolla A.K., Sutton D.J., 2012. Heavy metal toxicity and the environment. In Molecular, clinical and environmental toxicology. Springer, Basel, 133-164.

Thao N.P.H., Ha N.T.H, Anh B.T.K., 2016. Sorption of heavy metals by laterite from Vinh Phuc and Hanoi. Vietnam. Journal of Vietnamese Environment, 8(4), 235-239.

Thuy P.T., Mai N.T.T., Khai N.M., 2016. Production of adsorbent from red mud for the removal of arsenic in aqueous environment. VNU Journal of Science-
Earth and Environmental Sciences, 32(1S), 370-376.

Tran H.N., Chao H.P., 2018. Adsorption and desorption of potentially toxic metals on modified biosorbents through new green grafting process. Environmental Science and Pollution Research, 1-13.

Uddin M.K., 2017. A review on the adsorption of heavy metals by clay minerals, with special focus on the past decade. Chemical Engineering Journal, 308, 438-462.

Valenzuela D.F.R., Santos P.D.S., 2001. Studies on the acid activation of Brazilian smectitic clays. Quimica Nova, 24, 345-353.

Vlasova M., Leon I., Enriquez Mendez Y., DominguezPatino G., Kakazey M., Dominguez-Patino M., Nikolic M.V., Ristic M.M., 2007. Monitoring of transformations in bentonit after NaOH-TMA treatment. Ceramics International, 33, 405-412.

Wasastjerna J.A., 1923. On the radii of ions. Acta Societatis Fennicae Scientiarum, 1(38), 1-25.

Xiong W., Peng J., 2008. Development and characterization of ferrihydrite-modified diatomite as a phosphorus adsorbent. Water Research, 42(19), 4869-4877.

Yang J., Zhou L., Zhao L., Zhang H., Yin J., Wei G., Qian K., Wang Y., Yu C., 2011. A designed nanoporous material for phosphate removal with high efficiency. Journal of Materials Chemistry, 21, 2489-2494.

Zaidi N.M., Lim L.B.L., Usman A., 2018. Enhancing adsorption of $\mathrm{Pb}$ (II) from aqueous solution by $\mathrm{NaOH}$ and EDTA modified Artocarpus odoratissimus leaves. Journal of Environmental Chemical Engineering, 6(6), 7172-7184. 